\title{
Mitigating effects of acetylcholine supply on soybean seed germination under osmotic stress
}

\author{
Inaê Braga ${ }^{1}$ - Maria Dolores Pissolato ${ }^{2}$ Gustavo Maia Souza ${ }^{3}$
}

Received: 18 July 2016/ Accepted: 6 February 2017/Published online: 23 February 2017

(C) Botanical Society of Sao Paulo 2017

\begin{abstract}
Acetylcholine (Ach) is a common neurotransmitter in animals, also synthesized in plants, which can have an influence on plant response to stress, also acting as a signaling molecule between root and shoot. The objective of this study was to analyze the possible mitigating effects of exogenous application of Ach on soybean germination under different levels of osmotic potential. The experiments were conducted with soybean [Glycine $\max (\mathrm{L}$.) Merrill] genotype Intacta. The seeds were first treated with Ach solutions with the following concentrations: 0.0 (control); $0.5 ; 1.0$ and $2.0 \mathrm{mM}$. Then, the seeds were subjected to two water potentials, -0.5 and $-1.0 \mathrm{MPa}$, reached by using mannitol solutions, for the induction of osmotic stress, and a control condition with distilled water. Thus, 12 treatments were established in a double factorial $4 \times 3$, with 4 levels of Ach and 3 osmotic potential treatments $(0.0,-0.5$ and $-1.0 \mathrm{MPa})$ with four replicates per treatment. The results showed that the concentration of $1.0 \mathrm{mM}$ Ach, without osmotic stress, presented higher values for total dry mass of the seedlings compared to the control treatment (without Ach supply). In the treatments conducted to test the effectiveness of Ach on the mitigation
\end{abstract}

Inaê Braga

inae_braga@yahoo.com.br

1 Programa de Pós-Graduação em Biologia Vegetal, Instituto de Biociências, Universidade Estadual Paulista "Júlio de Mesquita Filho" (UNESP), Rio Claro, SP, Brazil

2 Graduação em Ciências Biológicas Bacharelado, Universidade do Oeste Paulista (UNOESTE), Rod. Raposo Tavares, km 572, Presidente Prudente, SP CEP 19067-175, Brazil

3 Departamento de Botânica, Universidade Federal de Pelotas - UFPel, Campus Universitário, S/N, Cx. Postal 345, Pelotas, RS, Brazil of severe osmotic stress effects $(-1.0 \mathrm{MPa})$, results showed that the concentration of $0.5 \mathrm{mM}$ Ach showed positive results for the following parameters; dry weight of shoot, root dry weight, total dry mass, which were significantly higher than treatment under 1.0 MPa.

Keywords Abiotic stress - Glycine max . Neurotransmitter $\cdot$ Seedling growth

\section{Introduction}

Soybean [Glycine $\max (\mathrm{L}$.) Merrill] is originally from China and belongs to the Fabaceae family (Sediyama et al. 2009). Soybean seeds contain about $40-45 \%$ protein and $18-20 \%$ oil in their composition (Islam et al. 2010). It is one of the major commercialized crops of the world, considered to be a major commodity, and the main producers are the USA, Brazil and Argentina, which are also the main exporters (Barzotto et al. 2012).

Seed quality can be affected by several factors during the process of plant development under field conditions. Factors such as inadequate temperatures, water deficit in the soil, along with other environmental variables can slow down the process of germination and seedling emergence, causing the seeds to remain exposed to unfavorable soil conditions for a longer time (Barzotto et al. 2012). Water availability is a major limiting factor of germination and early seedling development in field conditions, since it has an important role in the activation of different metabolic processes with a straightforward relation to germination of seeds (Avila et al. 2007).

Drought is characterized as an abiotic stress factor related to decreased water content in the soil, subjecting the plants to water stress (Paiva and Oliveira 2006). Water 
stress is associated with reduced water availability and cellular dehydration (Maraghni et al. 2010). As the soil water content or the substrate decreases, initially it appears to reduce the germination rate and, consequently, tighter restrictions can operate upon seedling development (Marcos Filho 2005). For each species, there is an ideal amount of soil water potential, below which there is limited or even a suppression of germination (Maraghni et al. 2010).

In order to perform studies on the of response of plants subjected to water stress under laboratory conditions, aqueous substances with different levels of osmotic potential are used (Machado et al. 2001). Several substances are used in these studies to induce osmotic stress, such as PEG (polyethylene glycol), which, due to its molecular weight, cannot enter cells, and mannitol, which is a chemically inert molecule and non-toxic for plants (Avila et al. 2007).

Seeds subjected to water stress show a reduction in both growth speed and germination rate due to the decreased enzyme activity, inducing lower meristem development (Popinigis 1985; Avila et al. 2007). However, there are substances present in the seeds that can confer protection when subjected to stress, such as gibberellic acid, abscisic acid, ethylene and cellular compatible osmolytes (Manavalan et al. 2009; Balardin et al. 2011).

Recently, neurotransmitter molecules have also been found in plants performing functions related to the regulation of development under stress ( $\mathrm{Xu}$ and $\mathrm{Hu}$ 2014). Among the most widespread neurotransmitters studied in plants are $\gamma$-aminobutyric acid (GABA) and acetylcholine (Ach) (Bouché and Fromm 2004), adrenaline, noradrenaline, dopamine, serotonin and glutamate (Roschina 2001). These molecules have been related to the activation of seed and pollen germination, regulation of ion permeability, energy balance, morphogenesis, movements of root, leaves and stomata, regulation of electrical events and protection against stress (Roschina 2001).

Ach is a small neurotransmitter molecule widespread throughout the nervous system of animals (Wessler and Kirkpatrick 2008). It has also been found in organisms without nervous system such as bacteria, algae, protozoa, poriferans, fungi and plants (Horiuchi et al. 2003; Sagane et al. 2005). In plant's cells, Ach is synthesized in the stems, leaves, nodes and roots in response to stress, participating in the signaling processes between the root and the shoot (Murch 2006). Choline and acetyl-coenzyme A are responsible for Ach synthesis mediated by the enzyme choline acetyltransferase (ChAT). Once the Ach biosynthesis rate is correlated with the presence of their precursors and associated enzymes, Ach can influence the process of biosynthesis by regulating enzymes such as ChAT, acetyl-CoA carboxylase, choline kinase, cholinesterase and pseudocholinesterase (Wessler et al. 2001). The hydrolysis of Ach and its metabolic derivatives, choline and acetate, is made by the enzyme acetylcholinesterase (AChE) (Blusztajn et al. 1987).

Studies have shown that osmotic stress causes a decrease in the level of Ach in the roots and in the leaf abaxial epidermis of Vicia faba L. even when the shoot was hydrated, affecting stomatal movement. Thus, it is evident the importance of Ach in signal transduction between shoot and root, including in response to stress (Wang et al. 2003). According to Wang et al. (2003), Ach may have a stimulatory effect on stomatal control. This control is due to the presence of Ach receptors, called "Ach binding sites," found in the chloroplasts (Roschina 2001), in the membrane vacuoles (Gong and Bisson 2002) and in the plasma membrane of guard cells (Meng et al. 2001). In radish germination (Raphanus sativus L.), grown with and without addition of Ach, the growth and development of lateral roots into seedlings was observed, but no effect on the main stems and roots was found (Sugiyama and Tezuka 2011).

According to Daneluzzi (2012), the effects of Ach on germination and plant growth changes from species to species, calling for additional studies to elucidate its role in plant development. Thus, the main objective of this study was to analyze a possible mitigating effect of the exogenous supply of Ach on soybean germination under different levels of osmotic potential.

\section{Materials and methods}

The experiments were carried out with soybean [Glycine $\max ($ L.) Merrill] genotype Intacta.

Seeds were washed with distilled water and treated with systemic fungicide Vitavax ( $0.5 \mathrm{~mL}$ for $200 \mathrm{~g}$ of seed). For germination were used 200 seeds per treatment, disposed in three sheets of paper towel-type germitest (two sheets of base and cover), wrapped in a transparent plastic bag. Treatments with different concentrations of Ach were equivalent to 2.5 times the weight of the dry substrate of solutions with different Ach concentrations (0.0, 0.5, 1.0 and $2.0 \mathrm{mM}$ ) directly on the germitest sheets. Germination was carried out under different osmotic conditions $(-0.5$ and $-1.0 \mathrm{MPa}$ ) using two concentrations of mannitol (74.3 and $37.15 \mathrm{~g} \mathrm{~L}^{-1}$, respectively), and a control treatment without mannitol, established using distilled water. Therefore, the experiment was performed on a factorial design $4 \times 2$ (four Ach concentrations and two osmotic conditions) and four replicates.

The experiment was carried out in a Mangelsdorf-type germination chamber (ELETROLAB, São Paulo, BR) with a photoperiod of $12 \mathrm{~h}$ and temperature of 28 and $25^{\circ} \mathrm{C}$ day/night. 
Analyzed variables - The germination test followed the Rules for Seed Analysis (Brasil 2009). Germination $(\% \mathrm{G})$ - evaluations were performed at five (first count) and eight (final count) days after seeding was regarded as the number of seeds that produced normal seedlings, that is, the emergence and development of the main embryonic structures (Brasil 2009). Germination speed index (GSI)—calculated according to Maguire (1962). The first count $(\mathrm{FC} \%)$ - the percentage data used normal seedlings on the fifth day after the germination test.

Seedling vigor classification-the classification of normal seedlings in three categories: strong normal (SNS, vigorous), week normal (WNS, little vigorous) and abnormal (problem in your structure or injury) (Nakagawa 1999; Brasil 2009). Dry matters of seedlings-to test the growth of seedling, four replicates of 10 seeds each were used. The seeds were germinated according to the methodology for the test germination. The parameters were evaluated as follows: length of root (LR), shoot (LS) and total length $(\mathrm{LT}=\mathrm{LR}+\mathrm{LS})$; dry mass of the shoot (DMS), root (RMD) and dry matter total $(\mathrm{DMT}=\mathrm{DMS}+\mathrm{RMD})$, and by calculating the relationship between the dry mass of root and shoot $(\mathrm{R} / \mathrm{S})$. The dry mass analysis was conducted after oven drying at $60^{\circ}$ until a constant mass was achieved (Nakagawa 1999).

Data analysis - The data have been subjected to analysis of variance (ANOVA, $P=0.05$ ) and the mean of values were compared via the Tukey test $(P<0.05)$, using the statistical software SISVAR (5.1, Federal University of Lavras).

Additionally, the normalized variation index (NIV) was calculated using the following equation as described by Tattini et al. (2006):

$$
\begin{aligned}
& \mathrm{NIV}^{\text {Ach on control }}=\left(X_{\text {Ach }}-X_{\text {control }}\right) /\left(X_{\text {Ach }}+X_{\text {control }}\right) \\
& \operatorname{NIV}^{\text {Ach on mannitol }}=\left(X_{\text {Ach }}-X_{\text {mannitol }}\right) /\left(X_{\text {Ach }}+X_{\text {mannitol }}\right)
\end{aligned}
$$

where $X_{\text {Ach }}$ values are the concentrations of Ach $(0.5$, 1.0 and $2.0 \mathrm{mM}$ ) and $X_{\text {control }}$ is the treatment without Ach supply. These calculations were performed separately considering 1 -treatments with different concentrations of Ach with distilled water (Fig. 1), and 2treatments under $-1 \mathrm{MPa}$ with different concentrations of Ach, and $X_{\text {mannitol }}$ is the treatment without Ach supply (Fig. 2).

The NIV is a standardized index of phenotypic plasticity, allowing for the visualization of the real effect of the treatment via the analyzed parameters, taking positive or negative values in relation to the control treatment, and the mannitol treatment, with distilled water or under $-1 \mathrm{MPa}$, respectively.

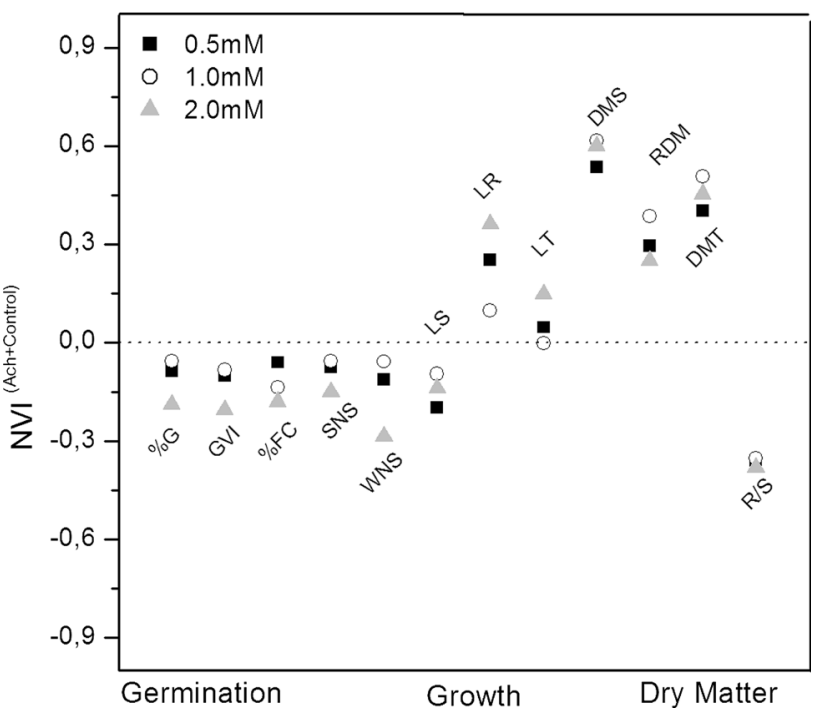

Fig. 1 Normalized variation index of percentage of germinated $(\% \mathrm{G})$, germination speed index (GSI), first count (\%FC), strong normal seedlings (SNS), weak normal seedlings (WNS), length shoot (LS), length root (LR), length total (LT), dry matter of shoot (DMS), root dry mass (RDM), total dry matter (DMT) and relationship between root and shoot $(\mathrm{R} / \mathrm{S})$ analyzed during the germination process [Glycine max (L.) Merrill] under Ach 0.0 MPa and osmotic conditions. The dotted horizontal line shows the normalized values of the treatment without the application of Ach

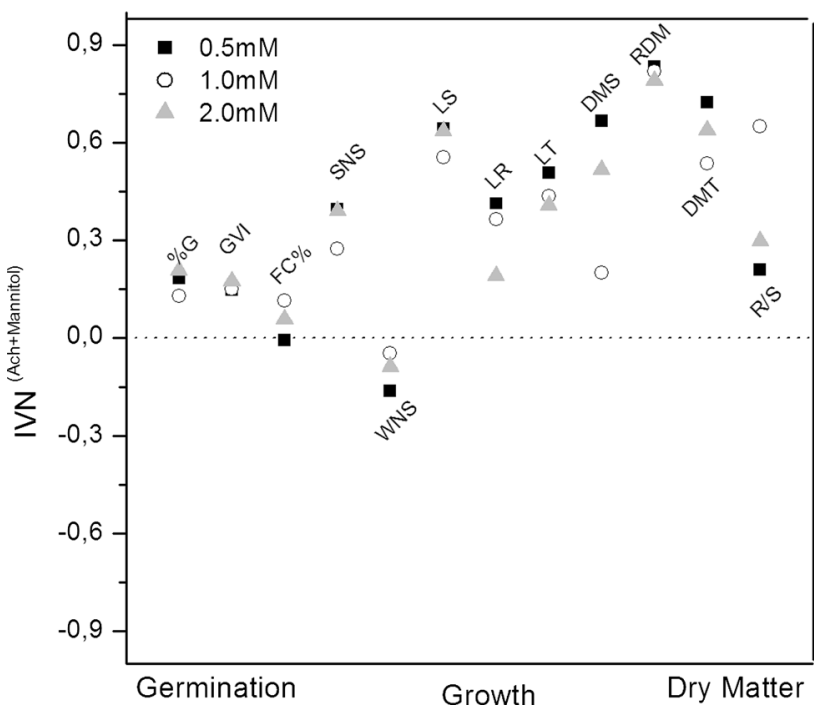

Fig. 2 Normalized variation index of percentage of germinated $(\% \mathrm{G})$, germination speed index (GSI), first count (\%FC), strong normal seedlings (SNS), weak normal seedlings (WNS), length shoot (LS), length root (LR), length total (LT), dry matter of shoot (DMS), root dry mass (RDM), total dry matter (DMT) and relationship between root and shoot $(\mathrm{R} / \mathrm{S})$ analyzed during the germination process [Glycine max (L.) Merrill] under conditions to Ach and osmotic $-1.0 \mathrm{MPa}$ (induced by mannitol). The dotted horizontal line shows the normalized values of the treatment without the application of Ach 


\section{Results}

The results of the exogenous supplying of Ach in the treatments without osmotic stress indicated that the concentration of $2.0 \mathrm{mM}$ showed positive effects on seedling growth parameters such as LR, LT, DMS and RDM compared to the control treatment (no Ach addition). As well as the observations in the $2.0 \mathrm{mM}$ concentration, the treatments with 1.0 and $0.5 \mathrm{mM}$ also induced a significant increase in DMT (DMS, and RDM). However, there was a decrease in the root and shoot relationship for all Ach concentrations evaluated when compared to control. On the other hand, no significant differences were observed for the germination parameters evaluated (Table 1).

In the treatments under $-1.0 \mathrm{MPa}$ of water potential, there was a significant reduction in all parameters evaluated, compared to the treatments with distilled water. On the other hand, there were no significant effects observed on the germination and initial growth of seedlings under water potential of $-0.5 \mathrm{MPa}$ (data not shown). Thus, these results will not be considered later.

In the treatments performed to test the effectiveness of Ach on mitigating the effects of severe osmotic stress $(-1.0 \mathrm{MPa})$, the results showed that the concentration of $0.5 \mathrm{mM}$ exhibited positive results on SNS, DMS, RDM, DMT, which were significantly higher than the $-1.0 \mathrm{MPa}$ treatment without the addition of Ach. The results showed that the concentration of $0.5 \mathrm{mM}$ caused positive effects on SNS, DMS, RMD, DMT, which were significantly higher than the $-1.0 \mathrm{MPa}$ treatment without the addition of Ach. The concentration of Ach $1.0 \mathrm{mM}$ showed a significant increase in the root-shoot relationship when compared to all other concentrations, including the control, while the concentrations of 0.5 and $2.0 \mathrm{mM}$ were statistically similar, inducing an increase in the $\% \mathrm{G}$ (Table 1).

The NIV control $_{\text {analysis with the different concentrations }}$ of Ach without the osmotic agent (Fig. 1) showed no significant differences among treatments in relation to germination traits. On the other hand, when taking into account the growth parameters of the seedlings, the treatment with $2.0 \mathrm{mM}$ of Ach showed increased $\mathrm{NIV}_{\text {control }}$ in the parameters of LR and LT $(0.3612$ and 0.1464 , respectively). A subtle decrease of -0.1973 was observed in the LS values in the concentration of $0.5 \mathrm{mM}$. However, the dry mass parameters in the concentration of $1.0 \mathrm{mM}$ showed an increase in the $\mathrm{NIV}_{\text {control }}$ values of DMS (0.6154), RDM (0.3846) and DMT (0.5054). Moreover, a decrease was observed in $\mathrm{NIV}_{\text {control }}$ for the $\mathrm{R} / \mathrm{S}$ ratio for all the Ach concentrations analyzed.

The results of NIV $\mathrm{V}_{\text {mannitol }}$ in seeds under osmotic stress (Fig. 2) showed a positive increase in all parameters analyzed; germination, growth and dry weight, in the three concentrations of Ach $(0.5,1.0$ and $2.0 \mathrm{mM})$.

The concentration of $0.5 \mathrm{mM}$ showed higher NIV $_{\text {mannitol }}$ values for the parameters of LR (0.4127), LT (0.5066), DMS (0.6667), RDM (0.8333) and DMT (0.7222). The highest values of $\mathrm{NIV}_{\text {mannitol }}$ were observed at R/S (0.6498) in the treatment with $1.0 \mathrm{mM}$ of Ach.

\section{Discussion}

In conditions without osmotic stress, the application of Ach showed a positive trend on the development parameters of the seedlings, but not on the germination traits. Many studies have suggested the involvement of Ach in regulating physiological processes in plants, especially in plant growth and in the development processes controlled by phytochrome (Tretyn et al. 1990). The Ach can induce similar effects to red light in the regulation of some photomorphogenic phenomena (Jaffe 1970; Tretyn 1987; Hartmann and Gupta 1989). Wild plants etiolated under red light irradiation showed an increase in the endogenous levels of Ach, and after application of a far-red light pulse, the reversal of this effect was observed (Wiśniewska and Tretyn 2003), suggesting that Ach must be related to the etiolation of plants, such as was observed herein with the application of $1 \mathrm{mM}$ in the germinated seeds under $-1.0 \mathrm{MPa}$ (Fig. 2). In this treatment, there was a greater increase in the LS $(\mathrm{NVI}=0.5547)$ in relation to the DMS $(\mathrm{NVI}=0.2000)$ compared with the treatment without the addition of Ach.

In this study, it was observed that the application of Ach in plants under osmotic stress $-1 \mathrm{MPa}$ (Table 1) promoted an elongation of the roots of seedlings. This phenomenon is dependent on the metabolic activity resultant in induction or inhibition of enzyme activity regulators in plant growth (Sugiyama and Tezuka 2011). Sugiyama and Tezuka (2011) carried out experiments with the application of Ach and observed the emergence and elongation of lateral roots in Vigna sesquipedalis (L.) Fruwirth, Avena sativa L. and Raphanus sativus (radish) grown in the dark. In particular, the effect of Ach was remarkable on radish seedlings. Different concentrations of Ach (0.1-100 nM), mainly $1 \mathrm{nM}$, induced higher growth, emergence and lateral root elongation, compared with control plants (Sugiyama and Tezuka 2011). According to Bamel et al. (2007), the formation of adventitial roots and secondary roots in detached leaves of tomatoes (Lycopersicon esculentum Mill.) grown in vitro was promoted by concentrations between $10^{-3}$ and $10^{-7} \mathrm{M}$, wherein $10^{-5} \mathrm{M}$ showed the best results.

Because rooting (in vivo or in vitro) is mainly affected by auxin, the effectiveness of Ach in promoting root grown 


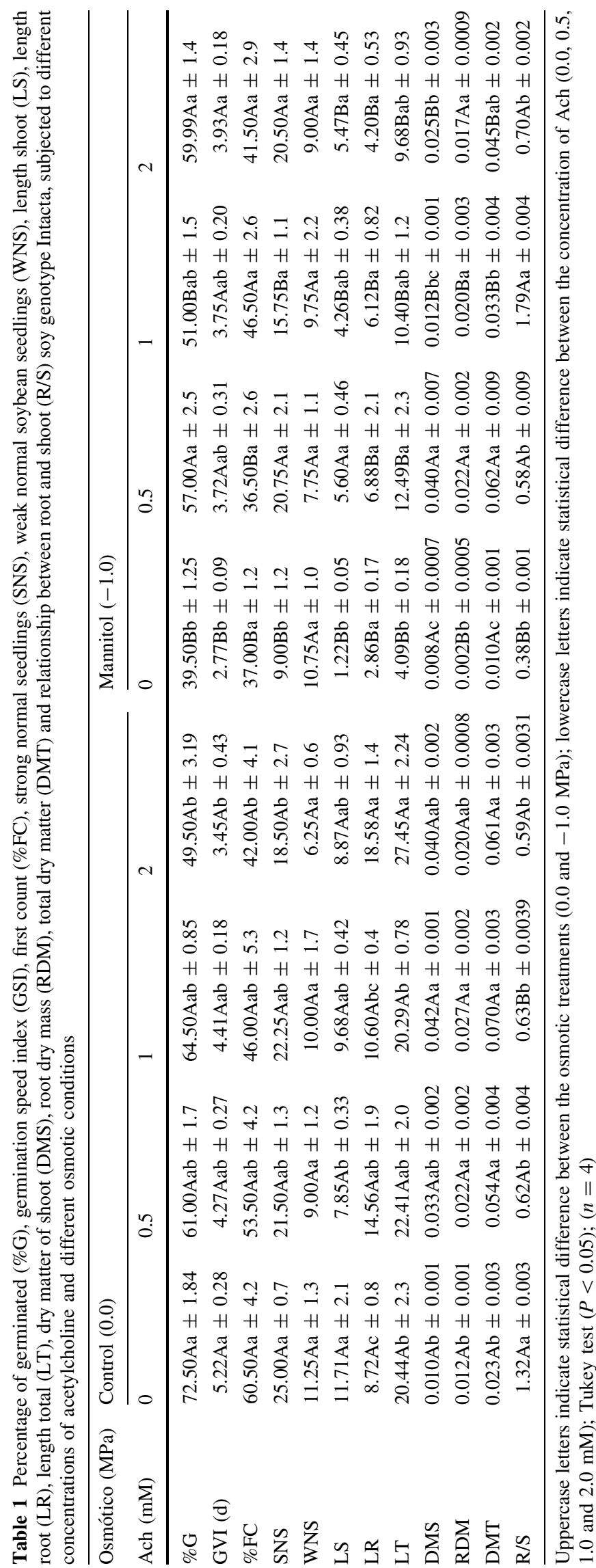


suggests an interesting possibility on the mechanism of action of Ach and its involvement with auxin (Baluska et al. 2005). Some experiments have shown that Ach combined with auxin increases the expression of the expansin LeEXPA2 gene in the hypocotyls of tomatoes, when compared to auxin and Ach treatments separately (Di-Sansebastiano et al. 2014). Expansins are known to be involved in cell elongation, being codified by a multigene family, where LeEXPA2 is included, which are regulated by auxin in the growing regions of young tomato hypocotyl (Caderas et al. 2000). Di-Sansebastiano et al. (2014) analyzed the expression of the expansin gene LeEXPA2 in tomato hypocotyls to investigate the effect of auxin and Ach in cell elongation. A low level of LeEXPA2 transcription in the treatment only with Ach was observed, but there was a significant increase in the transcription of expansins in the Ach treatments when combined with auxin.

In the results presented herein, there was no increase in LS under any of the tested concentrations of Ach under well-water conditions (Fig. 1). This result may be related to the concentrations used in the study. The literature provides no support for a clear definition of an optimal concentration of Ach to stimulate plant growth (DiSansebastiano et al. 2014). According to Lawson et al. (1978), the concentration of Ach $0-750 \mu \mathrm{M}$ results in an inhibitory effect on elongation of apical coleoptile in wheat (Avena sativa). However, Mukherjee (1980) tested higher concentrations of Ach in soybean seed germination, observing a stimulating effect on the elongation of hypocotyls. Parsaeimehr et al. (2015) observed that an exogenous application of $5 \mu \mathrm{g} \mathrm{L}^{-1}$ of Ach in Chlorella sorokiniana has a stimulatory role in the growth and accumulation of lipids. On the other hand, in Vigna sesquipedalis, there was suppression in the growth of hypocotyl and, simultaneously, there was an increase in epicotyl (Hoshino 1983).

Water stress induced by mannitol $(-1.0 \mathrm{MPa})$ significantly affected the traits analyzed regarding germination and seedling development (Table 1). These results are due to the reduction in water potential of the plant caused by mannitol, which reduces the water availability to seeds, promoting the reduction in enzyme activity, generating less meristematic development and thus reducing speed and the germination rate (Popinigis 1985; Avila et al. 2007).

The results from the application of Ach in the seeds germinated under osmotic stress have showed a remarkable mitigating effect of all tested concentrations of Ach, in relation to inhibition caused by the water potential of $-1.0 \mathrm{MPa}$. A concentration $0.5 \mathrm{mM}$ of Ach showed the best effect on the LS and LR, promoting greater dry matter accumulation (Table 1). According to Murch (2006), increased growth and cell wall thickness occur because
Ach is synthesized in the stems, leaves and root nodes in response to stress. Sugiyama and Tezuka (2011) analyzed the application of Ach in radish seeds, obtaining as a result a small effect on the fresh weight of the roots, while approximately a doubling of dry weight was observed. Ach exhibits an ability to increase the translocation of carbohydrates, such as sugars and starch, from the cotyledons to the roots, providing a higher elongation of roots and also higher biomass accumulation (Sugiyama and Tezuka 2011). Thus, Sugiyama and Tezuka (2011) suggested that Ach can activate some metabolic systems such as the glycolytic pathway in the cytoplasm, the TCA cycle and the electron transport system, as well as metabolic systems participating in increasing the amount of NAD, DNA and proteins. The mitigating effect of Ach found in this study is supported by other studies in the literature. Momonoki and Momonoki (1993), Roschina (2001) and Horiuchi et al. (2003) observed similar effects of Ach on various plants subjected to stress, suggesting it plays an important role in the response to environmental stimuli (Yamamoto and Momonoki 2012). These studies support the former observations of Kostir et al. (1965), suggesting that exogenous application of Ach influences the germination and the initial stage of development and growth of plants. The Ach, the enzyme that hydrolyzes the Ach (AchEacetylcholinesterase) and the Ach receptors (nicotinic, such as nAChRs, and muscarinic, such as mAChR) have been widely recognized in higher plants (Roschina 2001). In plants, although the genes encoding the Ach receptors (AchR) have not been identified, the named "binding sites of Ach" were found at chloroplasts (Roschina 2001) and at tonoplast (Gong and Bisson 2002). The Ach-mediated processes in plants can induce depolarization of the membranes, affecting the cell-to-cell transport of hormones and other substances (Momonoki 1997). The AchE gene was identified in Salicornia europaea L. by RT-PCR using primers from cloned maize genes, showing that the activity of AchE increased in the root due to the accumulation of $\mathrm{Na}^{+}$and $\mathrm{Cl}^{-}$. Therefore, it was proposed that Ach-mediated processes in Salicornia europaea may act in the elimination of excess salt in the epidermal cells of roots by improving cell-to-cell transport (Yamamoto et al. 2009).

As observed in our results, Ach promoted growth and dry matter accumulation in soybean seedlings under osmotic stress conditions, acting as a stress-mitigating agent, indicating that Ach must be involved in various metabolic processes of the plants. Czerpak et al. (2003) reported that Ach and taurine (a, chemical analogue of Ach) significantly stimulated the synthesis of some metabolites in Chlorella vulgaris Beijerinck, particularly monosaccharides and soluble proteins. Monosaccharides and soluble proteins may have an important role in osmotic adjustment in plants subjected to water stress (Morgan 
1984; Manavalan et al. 2009), which could explain, at least in part, the osmotic stress mitigation effects observed in our study.

Acknowledgements The authors acknowledge the funding Programa Institucional de Bolsas de Iniciação Científica (PIBIC) and Comissão de Aperfeiçoamento de Pessoal do Nível Superior (CAPES). M.D. Pissolato is scholarship PIBIC and I. Braga scholarship of doctorate CAPES.

\section{References}

Avila MR, Braccini AL, Scapim CA, Fagliari JR, Santos JL (2007) Influência do estresse hídrico simulado com manitol na germinação de sementes e crescimento de plântulas de canola. Rev bras sementes 29:98-106

Balardin RS, Silva FD, Debona D, Corte GD, Favera DD, Tormen NR (2011) Seed treatment with fungicides and insecticides as reducing the effects of water stress in soybean plants. Rural Sci 41:1120-1126

Baluska F, Volkmann D, Menzel D (2005) Plant synapses: actinbased adhesion domains for cell-to-cell communication. Trends Plant Sci 10:106-111

Bamel K, Gupta SC, Gupta R (2007) Acetylcholine causes rooting in leaf explants of in vitro raised tomato (Lycopersicon esculentum Miller) seedlings. Life Sci 80:2393-2396

Barzotto F, Facco L, Mattioni N, Farias JG, Segalin S (2012) Soybean cultivars response to germination under optimal sub-zero temperatures. Federal University of Santa Maria. http://www. unifra.br/eventos/sepe2012/Trabalhos/5625.pdf. Accessed 12 Feb 2015

Blusztajn JK, Liscovitch M, Richardson UI, Wurtman RJ (1987) Phosphatidylcholine as a precursor of choline for acetylcholine synthesis. In: Dawdall MJ, Hawthorne JN (eds) Cellular and molecular basis of cholinergic function. Ellis Horwood, Chichester, pp 341-346

Bouché N, Fromm H (2004) GABA in plants: just a metabolite. Trends Plant Sci 9:110-115

Brasil (2009) Ministério da Agricultura, Pecuária e Abastecimento. Regras para análise de sementes. Ministério da Agricultura, Pecuária e Abastecimento, Brasília. http://www.agricultura.gov. br/arq_editor/file/2946_regras_analise_sementes.pdf. Acessed 14 Feb 2014

Caderas D, Muster M, Vogler H, Mandel T, Rose JKC, McquennMason S, Kuhlemeier C (2000) Limited correlation between expansin gene expression and elongation growth rate. Plant Physiol 123:1399-1414

Czerpak R, Bajguz A, Jewiec P, Muszynska-Garstka M (2003) The influence of acetylcholine and taurine on the content of some metabolites in the alga Chlorella vulgaris. Ecohydrol Hydrobiol 3:223-229

Daneluzzi GS (2012) Uma abordagem neurofisiológica da acetilcolina em plantas de milho hidratadas e sob condições de estresse hídrico. Dissertação. Escola Superior de Agricultura "Luiz de Queiroz", Piracicaba

Di-Sansebastiano GP, Fornaciari S, Barozzi F, Piro G, Arru L (2014) New insights on plant cell elongation: a role for acetylcholine. Int J Mol Sci 15:4565-4582. doi:10.3390/ijms15034565

Gong XQ, Bisson MA (2002) Acetylcholine-activated $\mathrm{Cl}^{-}$channel in the Charatonoplast. J Membr Biol 188:107-113

Hartmann E, Gupta R (1989) Acetylcholine as a signaling system in plants. In: Boss WF, Morré DJ (eds) Second messengers in plant growth and development. A. R. Liss, New York, pp 257-288
Horiuchi Y, Kimura R, Kato N, Fujii T, Seki M, Endo T, Kato T, Kawashima K (2003) Evolutional study on acetylcholine expression. Life Sci 72:1745-1756

Hoshino T (1983) Effects of acetylcholine on the growth of the Vigna seedlings. Plant Cell Physiol 24:551-556

Islam MO, Rahim MA, Prodhan AKMA (2010) Flowering pattern, floral abscission and yield attributes in soybean influenced by GABA. J Bangladesh Agric Univ 8:29-33. doi:10.3329/jbau.v8i1.6394

Jaffe MJ (1970) Evidence for the regulation of phytochrome-mediated process in bean roots by the neurohumor, acetylcholine. Plant Physiol 46:768-777

Kostir J, Klenha J, Jiracek V (1965) The effect of acetylcholine on seed germination in agricultural plants. Rost Vyroba. 12:239-279

Lawson VR, Brady RM, Campbell A, Know BG, Knox GD, Walls RL (1978) Interaction of acetylcholine chloride with IAA, GA3 and red light in the growth of excised apical coleoptile segments. Bull Torrey Bot Club 105:187-191

Machado JC, Oliveira JA, Vieira MGGC, Alves MC (2001) Inoculação artificial de sementes de soja por fungos, utilizando solução de manitol. Rev bras sementes 23:95-101

Maguire JB (1962) Speed of germination-aid in selection and evaluation for seedling emergence vigor. Crop Sci 2:176-177

Manavalan LP, Guttikonda SK, Tran LSP, Nguyen HT (2009) Physiological and molecular approaches to improve drought resistance in soybean. Plant Cell Physiol 50:1260-1276

Maraghni M, Gorai M, Neffati M (2010) Seed germination at different temperatures and water stress levels, and seedling emergence from different depths of Ziziphus lotus. S Afr J Bot $76: 453-459$

Marcos Filho J (2005) Fisiologia de sementes de plantas cultivadas, vol 12. FEALQ, Piracicaba

Meng F, Liu X, Zhang S, Lou C (2001) Localization of muscarinic acetylcholine receptor in plants guard cells. Chin Sci Bull 46:586-587. doi:10.1007/BF02900416

Momonoki YS (1997) Asymmetric distribution of acetylcholinesterase in gravistimulated maize seedlings. Plant Physiol 114:47-53

Momonoki YS, Momonoki T (1993) Changes in acetylcholinehydrolyzing activity in heat-stressed plant cultivars. Jpn J Crop Sci 62:438-446

Morgan JM (1984) Osmoregulation and water stress in higher plants. Ann Rev Plant Physio 35:299-319

Mukherjee I (1980) The effect of acetylcholine on hypocotyl elongation in soybean. Plant Cell Physiol 21:1657-1660

Murch SJ (2006) Neurotransmitters, neuroregulators and neurotoxins in the life of plants. Commun Plants. doi:10.1007/978-3-54028516-8_10

Nakagawa J (1999) Teste de Vigor baseados no desempenho das plântulas. In: Krzyzanowski FC, Vieira RD, França-Neto JB (eds) Vigor de Sementes: Conceitos e Testes. ABRATES, Londrina, pp 2-24

Paiva R, Oliveira LM (2006) Physiology and plant production. UFLA, Lavras

Parsaeimehr A, Sol Z, Dou X, Chen YF (2015) Simultaneous improvement in production of microalgal biodiesel and highvalue alpha-linolenic acid by a single regulator acetylcholine. Biotechnol Biofuels 8:11. doi:10.1186/s13068-015-0196-0

Popinigis F (1985) Fisiologia da semente. Ministério da Agricultura AGIPLAN, Brasília

Roschina VV (2001) Neurotransmitters in plant life. Science Publishers, Enfield

Sagane Y, Nakagawa T, Yamamoto K, Michikawa S, Oguri S, Momonoki YS (2005) Molecular characterization of maize acetylcholinesterase. a enzyme family in the plant kingdom. Plant Physiol 138:1359-1371 
Sediyama T, Teixeira RC, Barros HB (2009) Origem evolução e importância econômica. In: Sediyama $\mathrm{T}$ (ed) Tecnologia de produção e usos da soja, Editora Mecenas, Londrina, pp 1-5

Sugiyama KI, Tezuka T (2011) Acetylcholine promotes the emergence and elongation of lateral roots of Raphanus sativus. Plant Signal Behav 6:1545-1553

Tattini M, Remorini D, Pinelli P, Agati G, Saracini E, Traversi M, Massai R (2006) Morpho-anatomical, physiological and biochemical adjustments in response to root zone salinity stress and high solar radiation in two Mediterranean evergreen shrubs, Myrtus communis and Pistacia lentiscus. New Phytol 170:779-794

Tretyn A (1987) Influence of red light and acetylcholine on $\mathrm{Ca}^{2+}$ uptake by oat coleoptile cells. Cell Biol Int Rep 11:887-896

Tretyn A, Bossen ME, Kendrick RE (1990) The influence of acetylcholine on the swelling of wheat (Tritricum aestivum L.) protoplasts. J Plant Physiol 136:24-29

Wang H, Zhang S, Wang X, Lou C (2003) Involvement of $\mathrm{Ca}^{2+} \mathrm{CaM}$ in the signal transduction of acetylcholine-regulating stomatal movement. Chin Sci Bull 48:351-354
Wessler I, Kirkpatrick CJ (2008) Acetylcholine beyond neurons: the non-neuronal cholinergic system in humans. $\mathrm{Br} \mathrm{J}$ Pharmacol 154:1558-1571

Wessler I, Kilbinger H, Bittinger F, Kirpatrick CJ (2001) The biological role of non-neuronal acetylcholine in plants and humans. Jpn J Pharmacol 85:2-10

Wiśniewska J, Tretyn A (2003) Acetylcholinesterase activity in Lycopersicon esculentum and its phytochrome mutants. Plant Physiol Bioch 41:711-717. doi:10.1016/S0981-9428(03)001116

Xu JG, Hu QP (2014) Changes in $\gamma$-aminobutyric acid content and related enzyme activities in Jindou 25 soybean (Glycine max L.) seeds during germination. Lwt Food Sci Technol 55:341-346

Yamamoto K, Momonoki YS (2012) Tissue localization of maize acetylcholinesterase associated with heat tolerance in plants. Plant signal Behav 7:301-305. doi:10.4161/psb.19

Yamamoto K, Oguri S, Chiba S, Momonoki YS (2009) Molecular cloning of acetyl-cholinesterase gene from Salicornia europaea L. Plant Signal Behav 4:361-366. doi:10.4161/Psb.4.5.8360 